\title{
THE ROLE OF THE MARSHAL OF THE VOIVODSHIP IN THE PROTECTION OF TRAVELLERS IN THE EVENT OF THE INSOLVENCY OF TOUR OPERATORS AND RELATED TOURIST SERVICES
}

\author{
Tomasz Brzezicki*, Dorota Sylwestrzak**
}

\begin{abstract}
The authors briefly present the issues of the protection of travellers in case of the insolvency of tour operators and related tourist services. The reflections are primarily focused on the analysis of the tasks of the Marshal of the Voivodship in this respect and their legal nature. The subject of the study is primarily to present the current legal status, the position of the judiciary, and a legal and comparative analysis of the EU regulations with Polish regulations. The analysis is carried out from the perspective of the legitimacy of entrusting these tasks to the Marshal of the Voivodship, and consequently ensuring the effective protection of travellers. The article uses the theoretical-dogmatic, historical, and legal-comparative method. The reflections are based on a comparison of selected institutions of law functioning in the system of Polish law and legal solutions in force in EU law.
\end{abstract}

Key words: traveller, tourist services, insolvency

* Ph.D., Assistant Professor at the Department of Administrative Law, Nicolaus Copernicus University in Toruń, legal advisor, brzoza@umk.pl, ORCID: 0000-0003-1048-1402.

* Ph.D., Assistant Professor at the Department of Administrative Law, Nicolaus Copernicus University in Toruń, legal advisor, d_syl@law.uni.torun.pl, ORCID: 0000-00034985-2880. 


\section{INTRODUCTION}

In Poland, tourism plays an important role and enjoys unchanging popularity, which contributes to the development of economic activity in this sector. This popularity also forces entrepreneurs providing tourism services to undertake a number of activities related, not only to ensuring the attractiveness of the offer, but also safety for travellers. Their protection takes place at the level of EU and national law, the Polish Constitution, and legislation. This is achieved by means of both substantive and procedural regulations. Travellers' interests are protected by various bodies, including the President of the Office of Competition and Consumer Protection, the District (City) Consumer Ombudsman, governmental (central and local) and local government administration bodies, as well as judicial authorities. The rights of travellers are protected both in private and public law. The subject matter of the article will be primarily an analysis of public-legal institutional solutions for the protection of the rights of travellers in the field of tourism and related services, limited to the issue of protection of travellers in the situation of insolvency of tourist events operators and providers of related services. The issue of insolvency of entities providing tourism services is an extremely important problem, not only for the Polish legislator, but also in EU law. On 25 November 2015, the European Parliament adopted Directive 2015/23021 . The Polish legislator implemented this Directive in the Act of 24 November 2017 on Tourist Events and Related Tourism Services ${ }^{2}$.

The aim of the study will be to present legal solutions in Polish law, to compare them with the solutions adopted in Directive 2015/2302, and to assess the legal nature of the tasks entrusted to the Marshal regarding the insolvency of entities providing tourism services in the context of typical public administration tasks. The key issue will be to answer the follow-

1 Directive (EU) No. 2015/2302 of the European Parliament and of the Council of 25 November 2015 on package travel and related tourism services, amending Regulation (EC) No. 2006/2004 and Directive 2011/83/EU of the European Parliament and of the Council and repealing Council Directive 90/314/EEC, OJ EU.L 326, p. 1, hereinafter referred to as Directive 2015/2302.

2 Consolidated text, Journal of Laws 2019, item 548, hereinafter referred to as TERTS. 
ing questions: are these tasks within the scope of public administration or not, and should they really be entrusted to the Marshal of the Voivodship, and, if they are not tasks within the scope of public administration, what entity would be the right one, and do the implemented solutions really properly protect the interests of travellers?

\section{TASKS IN CASES OF INSOLVENCY OF TOURISM SERVICE PROVIDERS AND ADMINISTRATIVE BODIES COMPETENT IN THESE CASES - THE ORIGIN OF POLISH AND EU REGULATION UNTIL THE IMPLEMENTATION OF DIRECTIVE 2015/2302}

Under the Tourism Services Act $1997^{3}$, the tasks relating to the protection of the rights of travellers where the tour operator, despite its obligation, did not ensure that their return home was entrusted to a licensing authority, i.e. the President of the Office for Sports and Tourism, who was authorised, on the basis of the contents of a guarantee or insurance contract, to issue instructions for the payment of funds for the return of travellers to their home country.

As a result of the amendment of the Tourism Services Act of 19994, these tasks were entrusted to the authority issuing the permit to conduct business activity consisting in organizing tourist events and acting as an intermediary at the request of the traveller in concluding contracts for the provision of tourist services, i.e. a Voivode. A Voivode or an entity designated by him or her has been authorised to issue an order for the settlement of an advance payment to cover the costs of the traveller's return to their home country on the basis of a guarantee or insurance contract (Article 5 (3)). Pursuant to the amendment to the Tourism Services Act of 2000, Article $5(4)^{5}$ was added, which authorised a Voivode to act for

3 Art. 5 (3) of the Act of 29 August 1997 on tourism services, Journal of Laws No. 133, item 884 in its original wording, currently not in force.

4 The Act of 10 April 1999 amending the Tourism Services Act, Journal of Laws No. 40 , item 401.

5 Article 4 (4) of the Act of 8 December 2000 amending the Act on Higher Education, the Act on Higher Vocational Schools, the Act on Railway Transport, and the Act on Tourism Services, and the Act - Code of Civil Procedure, the Act - Law on the System 
the benefit of travellers in cases of payment of funds under a bank guarantee agreement, insurance guarantee agreement or insurance contract, on the terms specified in the content of such agreements. As a result of this amendment also section 5 was added, which provided that from the sum specified in the bank guarantee agreement, insurance guarantee agreement, or insurance contract the costs of bringing the travellers to their home country are covered first. If the remaining amount of the guarantee is insufficient to return all payments made by the clients, payments are reduced in proportion to the remaining amount.

The Marshal of the Voivodship has been delegated the tasks previously vested in the Voivodship in terms of ensuring the return of travellers to their home country in a situation where the tour operator has not fulfilled the obligations incumbent on it, pursuant to Article 16 (1) of the Act of 29 July 2005 amending certain acts in connection with changes in the division of tasks and responsibilities of local administration ${ }^{6}$. At that time it was assumed that these tasks are tasks of government administration (Article 2a of the Tourism Services Act).

Another important change was introduced by an amendment to the Act of 12 June 20157, pursuant to which, in Article 5 of the Act, a section 5a was added specifying the tasks of the Marshal of the Voivodship in the event of the insolvency of a tour operator or tourist intermediary. The legislator decided that the Marshal of the Voivodship or an entity indicated by him or her is authorised to issue an advance payment order to cover the costs of travellers' return to their home country. Moreover, the legislator imposed an obligation on the body to carry out activities related to the organisation of the return of travellers from the tourist event to the place of departure or planned return from the tourist event, if the tour operator or tourist intermediary, contrary to the obligation, did not ensure such return. It should be noted that it was only in the June amendment of 2015 that the legislator used the concept of "insolvency" for the first time. This concept raises

of Common Courts, and the Act on Government Administration Departments - in connection with the adjustment to the law of the European Union, Journal of Laws No. 122, item 1314.

6 Journal of Laws No. 175, item 1462.

7 Article 1 of the Act of 12 June 2015 amending the Tourism Services Act, Journal of Laws of 2015, item 1164. 
a number of interpretative doubts in the doctrine ${ }^{8}$. Nevertheless, it is agreed that the notion of insolvency of the tourism services provider is not a concept identical to insolvency within the meaning of Article 11 (1) and (1a) of the $\mathrm{BL}^{9}$, and, in fact, it refers to "a situation in which the tour operator has ceased to provide the services to which it has committed itself in its contract with the traveller" ${ }^{\prime 10}$. It should be stressed that the previous Tourism Services Act was an implementation of Directive 90/314/EEC ${ }^{11}$. Nevertheless, both the application of Article 7 of Directive 90/314/EEC ${ }^{12}$ and Article 5 of the Tourism Services Act have raised a number of interpretative doubts in the doctrine ${ }^{13}$. In the case law, the doubts of interpretation concerned, e.g., the question of the extent of the protection of travellers, and in particular, what kind of expenses are to be reimbursed, the specification of the upper limit of liability, and the pursuit of these claims from the competent administrative authorities. Directive 90/314/EEC did not specify the amount of the cover, but nevertheless gave some indication that the organiser and/or

8 D. Szafran, Ochrona konsumenta w razie niewypłacalności biura podróży, Acta Erasmiana XIII (2016), M. Sadowski, ed., Wrocław: 101-103.

9 The Act of 28 February 2003, Bankruptcy Law, consolidated text, Journal of Laws 2019, item 498, as amended, here in after referred to as BL. According to Article 11(1) of the $\mathrm{BL}$, a debtor is insolvent if it has lost the ability to meet its due monetary obligations. In turn, in accordance with Article 11 (1a) of the BL it is presumed that the debtor has lost the ability to meet its due monetary obligations if the delay in meeting monetary obligations exceeds three months.

${ }_{10}$ K. Marak, Niewypłacalność organizatora turystyki i przedsiębiorcy ułatwiającego nabywanie powiązanych usług turystycznych - uwagi na tle nowych regulacji prawnych z zakresu turystyki, In: Restrukturyzacja przedsiębiorcy i jego przedsiębiorstwa, M. Kuźnik, A.J. Witosz, ed., Warszawa (2018): Legalis/el.; D. Szafran, Ochrona konsumenta w razie niewypłacalności biura podróży, Acta Erasmiana XIII (2016), M. Sadowski, ed., Wrocław: 101-103.

11 Council Directive of 13 June 1990 on package travel, package holidays, and package tours, OJ EU.L 158, p. 59, currently not in force, hereafter as Directive 90/314/EEC.

12 According to Article 7 of Directive 90/314/EEC, in the event of insolvency, the organiser and/or retailer being a party to the agreement should provide sufficient security to allow for the reimbursement of overpaid money and for the return of the consumer from the trip.

13 P. Cybula, Usługi turystyczne. Komentarz (2012): LEX/el.; D. Szafran, Ochrona konsumenta w razie niewypłacalności biura podróży, Acta Erasmiana XIII (2016), M. Sadowski, ed., Wrocław: 104-108. 
retailer was obliged to provide sufficient cover in the event of its insolvency to allow for the return of the money overpaid and the return from the trip (Article 7 of Directive 90/314/EEC). The Court of Justice of the EU has repeatedly stressed in rulings issued on the basis of Article 7 of Directive 90/314/EEC the need to protect travellers in the event of the organiser's insolvency. In the view of the CJEU, the scope of the protection of travellers in the event of the insolvency of travel agents includes ensuring the return of the traveller from the trip and the reimbursement of the amounts paid for the failed event, the reimbursement of the advance or full payment for the event, and ensuring return to the place of commencement of the event (if the organiser has failed to provide it owing to the insolvency) and in addition the cost of the necessary additional accommodation ${ }^{14}$. Travellers have been granted the right to seek individual compensation from the State Treasury $^{15}$. In Polish judicature a problem has arisen in those situations where the required security funds were not sufficient to cover even the costs of return to their home country. It was assumed that there are no legal

14 Cf. the judgments of the CJEU of: 8 October 1996 on cases (Erich Dillenkofer and others v. the Federal Republic of Germany) C-178/94, C-179/94, C-189/94 i C-190/94, http://eur-lex.europa.eu, 14 May 1998, case (Verein für Konsumenteninformation v. Österreichische Kreditversicherungs AG) C-364/96, http://eur-lex.europa.eu, 15 June 1999, (Walter Rechberger and Others v. Republic of Austria) C-140/97, http://eur-lex. europa.eu. Decision of the CJEU of 16 January 2014, Ilona Baradics and Others v. Qbe Insurance (Europe) LTD MagyAroszàgiFióktelepe and Magyar Állam) C-430/13, http:// eur-lex.europa.eu. This is also the case in the Polish judicature, the judgment of the District Court in Warsaw $-27^{\text {th }}$ Civil Appeals Division of 28 April 2017, XXVII Ca 4173/16, Legalis Number 2132787. See also: A. Jurkowska-Gomułka, Glosa do wyroku TS z dnia 16 lutego 2012 r., C-134/11, LEX/el. 2012; P. Dzienis, Bezprawność legislacyjna w postaci niewłaściwej implementacji dyrektywy unijnej 90/314/EWG w polskiej judykaturze, EPS 7 (2018): 4-10; P. Cybula, P. Czubik, Pomoc finansowa konsula jako instrument ochrony klienta niewypłacalnego organizatora turystyki, EPS 12 (2014): 20-27.

15 Resolution of the Supreme Court of 19 May 2016, III CZP 18/16, Legalis Number 1446707. In the quoted resolution, a client of an insolvent travel agency was granted a legal basis "to claim from the insurer obliged under the insurance guarantee the return of payments made as payment for a travel event". M. Sekuła-Leleno, Legitymacja procesowa czynna klientów niewypłacalnych biur podróży do samodzielnego dochodzenia roszczeń przed sądem. Glosa do uchwały SN z dnia 19 maja 2016 r., III CZP 18/16, Glosa 1 (2017): 123-132; M. Sondej, Klient niewypłacalnego biura podróży może samodzielnie dochodzić zwrotu dokonanych wpłat, LEX/el. 2017. 
grounds to claim that "the Marshal of the Voivodship is obliged to organize the return of tourists to Poland regardless of the costs, i.e. also beyond the guarantee funds" 16 . This problem concerned, e.g., the question of who should cover these costs. In one of the judgments, the Supreme Court ${ }^{17}$ stated that "the State Treasury is not obliged to reimburse the Marshal of the Voivodship for the costs of arranging for the clients of an insolvent tour operator to return to Poland on the basis of Article 49 (6) of the Act of 13 November 2008 on the income of local government units ${ }^{18}$ in the event of an insufficient guarantee amount resulting from a bank or insurance guarantee agreement to cover these costs". In the quoted judgment, the Supreme Court indicated that "the Marshal may effectively initiate a civil law guarantee mechanism in order to obtain appropriate coverage of the said organisational expenses. However, there are no justified grounds for claiming that in the case of an insufficient guarantee amount resulting from the guarantee agreement, the Marshal has ex lege an independent legal obligation to undertake organisational activities aimed at bringing the tour operator's clients to their home country and the performance of this obligation also makes it necessary to mobilise appropriate funds from the local government budget. The provisions of the Act of August 29, 1997 did not create and still do not create, after the rejection of the above mentioned legislative attempts to introduce in this case subsidiary liability of the State Treasury, an additional legal instrument serving the legal protection of the tour operator's clients and supplementing the general model. In other words, the current model of protection, referring to safeguards provided for in Article 5 (1), item 2 of the Act, has not, however, been supplemented by the regime of organizing budgetary resources of voivodship local governments in case the tour operator is unable to fulfil the obligation to ensure return of its clients to their home country"19.

16 Judgment of the Court of Appeal in Warsaw of 28 May 2015, I ACa 1768/14, Legalis Number 1349079.

17 Judgment of the Supreme Court of 15 October 2015, II CSK 836/14, Legalis Number 1360063; K. Małysa-Ptak, Zwrot kosztów powrotu do kraju. Glosa do wyroku SN z dnia 15 października 2015 r., II CSK 836/14, PS 7-8 (2016): 171-181.

18 Consolidated Text, Journal of Laws 2018, item 1530, as amended.

19 Judgment of the Supreme Court of 15 October 2015, II CSK 836/14, Legalis Number 1360063. 
Already then the doctrine called for the establishment of a special fund to cover travellers' claims against insolvent travel service providers ${ }^{20}$. Further changes, important from the point of view of protecting the rights of travellers in the situation of insolvency of entrepreneurs providing tourism services, were introduced in another amendment in July $2016^{21}$. As a result, it was decided to establish the Tourist Guarantee Fund. It is provided that in the event of insolvency, the tour operator or tourist intermediary is obliged to submit to the competent Marshal of the Voivodship: a declaration of insolvency ${ }^{22}$ and a list of agreements limited to those which have not been or will not be performed together with information containing names and contact telephone numbers of persons covered by the agreement. It has been assumed that the Marshal may issue an instruction to withdraw funds from financial security schemes without obtaining the declaration of the insolvent entrepreneur if the circumstances clearly indicate that the tour operator or tourist intermediary is not able to fulfil the agreements on provision of tourist services concluded with the clients

20 D. Szafran, Ochrona konsumenta w razie niewypłacalności biura podróży, Acta Erasmiana XIII (2016), M. Sadowski, ed., Wrocław: 108; E.J. Wanat-Połeć, G.A. Sordyl, Wzmocnienie ochrony konsumentów niewypłacalnych touroperatorów w Polsce a koncepcja utworzenia Turystycznego Funduszu Gwarancyjnego, Annales Universitatis Maria Curie-Skłodowska, Lublin, Vol. XLIX, 4 (2015), sectio H: 634-648, DOI: 10.17951/h.2015.49.4.633, http://oeconomia.annales.umcs.pl [date of access: 13 October 2019]: 633-648; H. Zawistowska, Systemy zabezpieczenia finansowego interesów nabywców imprez turystycznych na wypadek niewypłacalności ich organizatorów w państwach członkowskich UE, In: P. Cybula, J. Raciborski, ed., Turystyka a prawo. Aktualne problemy legislacyjne i konstrukcyjne, (2008) Wyższa Szkoła Turystyki i Ekologii w Suchej Beskidzkiej, Sucha Beskidzka-Kraków, http:// wtir.awf.krakow.pl/pdf/rozne/zaklad_prawa/turystyka_a_prawo/21-hanna_zawistowska.pdf [date of access: 13 October 2019].

21 Article 1 of the Act of 22 July 2016 amending the Act on Tourism Services and the Act on Compulsory Insurance, the Insurance Guarantee Fund and the Polish Motor Insurers' Bureau, Journal of Laws 2016, item 1334, hereinafter referred to as an amendment of July 2016.

22 According to Article 5 (3e), item 1 of the Tourism Services Act, the content of the statement was to read: "I declare that owing to insolvency I am not able to fulfil the contracts for the provision of tourism services concluded with clients in the period from... to... and to ensure that the costs of clients' return from the tourist event are covered and to ensure that clients are reimbursed for payments or parts of payments made as payment for the tourist event pursuant to Article 5 (1), item 2 of the Act of 29 August 1997 on tourism services". 
and to ensure that the costs of clients' return from the tourist event are covered and to provide the clients with a refund of payments or parts thereof made as payment for the tourist event which has not been or will not be fulfilled (Article 5 (3f) of the Tourism Services Act). The competence of the Marshal of the Voivodship has been extended to include the right to apply for payment of funds from the Tourist Guarantee Fund (Article 5, Article 5b-5m of the Tourism Services Act).

\section{TASKS AND ADMINISTRATIVE BODIES COMPETENT \\ IN CASES OF INSOLVENCY OF TOURISM SERVICES PROVIDERS \\ FOLLOWING IMPLEMENTATION OF DIRECTIVE 2015/2302}

Another milestone in the protection of travellers' rights was the adoption of Directive 2015/2302 and the need to implement it into Polish law. According to Recital item 39 of Directive 2015/2302, Member States are obliged to ensure: (1) travellers purchasing a package holiday event are fully protected in the event of the organiser's insolvency, (2) organisers have a security to ensure that all payments made by or on behalf of travellers are reimbursed and, in so far as the package holiday involves the transportation of passengers, travellers are returned to their home country in the event of the organiser's insolvency, including the possibility of offering continuation of the package holiday to travellers, 3) the effectiveness of the protection, understood as the obligation to ensure the immediate activation of the protection when, as a result of the organiser's problems with liquidity, the travel services are not provided, will not be provided or will be provided only partially, or when service providers require the travellers to pay for them, 5) the possibility of requiring the organisers to provide the travellers with a certificate proving their right to receive benefits directly from the provider of insolvency protection ${ }^{23}$. Article 17 (1)

23 More: M. Nesterowicz, Dyrektywa Unii Europejskiej o imprezach turystycznych i powiązanych usługach turystycznych, jej implementacja do prawa polskiego i odpowiedzialność biur podróży, Przegląd Sądowy 9 (2018): 44-57; P. Dolniak, Zakres ochrony finansowych interesów klientów biur podróży na wypadek niewypłacalności przedsiębiorcy w świetle prawa unijnego, Palestra 3 (2018): 12-18. 
of Directive 2015/2302 provides that tour operators must have security for the reimbursement of all payments made by or on behalf of travellers to the extent that the services in question have not been provided as a result of the organiser's insolvency, including for the return of travellers to their home country, as well as for the continuation of the package holiday. This security must be effective and cover reasonably foreseeable costs, i.e. the amounts of payments made by or on behalf of travellers for the package holiday, taking into account the length of time between advance and final payments and the completion of the package holiday, as well as the estimated cost of return to their home country in the event of the organiser's insolvency. Protection of the organiser in the event of insolvency shall cover travellers regardless of their place of residence, place of departure, or place of sale of the package tour, and regardless of the Member State in which the insolvency protection provider is located. Where the implementation of the package tour is jeopardised by the insolvency of the tour operator, the protection shall be available free of charge to ensure return to their home country or, where necessary, to pay for accommodation before return to their home country. In the case of a tourism service not provided, refunds should be made without undue delay upon request of the traveller (Article 17 (5) of Directive 2015/2302).

In view of the need to implement the Directive, a law on tourist events and related tourism services was adopted, which entered into force on 1 July 2018. The previous title of the Act on Tourism Services under Article 64 (1) of the Act of 24 November 2017 on tourist events and related tourism services ${ }^{24}$ became the Act on Hotel Services and the Services of Tour Leaders and Tour Guides. The legislator has decided to implement Directive 2015/2302 in a separate legal act, briefly referring in the justification of the project to novelties in the form of "related tourist services, facilitating the purchase of such services, standard information forms, and changes in the functioning system of financial security in the event of insolvency for tour operators and tour intermediaries, in particular as regards the process of liquidation of the consequences of the insolvency of tour operators and the possibility of reimbursement of contributions paid to

${ }^{24}$ Journal of Laws 2017, item 2361 in its original wording. 
the Tourism Guarantee Fund"25. The question arises whether the legislator has legitimately separated the above regulations? Should the above issues not be regulated in one legal act? In the opinion of the authors, the regulations concerning the provision of tourism services, owing to the broadly understood definition of this notion covering (transportation of passengers, accommodation for purposes other than residential, which is not an integral part of passenger transportation, rental of cars or other motor vehicles and other service provided to travellers), should be included in a single legal act.

The main objective, apart from the transposition of Directive 2015/2302 into the Polish legal order, was, as follows from the content of the explanatory memorandum of the draft act, "improvement of already functioning legal solutions, in particular as regards the protection of travellers against the effects of insolvency of tour operators and entrepreneurs facilitating the purchase of tourist services" ${ }^{\prime 26}$. The question arises whether the new act introduced effective solutions to protect the rights of travellers against the insolvency of tourist entrepreneurs and the process of liquidation of the effects of insolvency.

\section{THE ESSENCE OF THE PROBLEM - INSOLVENCY}

From the perspective of the subject matter of the discussion, in order to initiate the tasks of the Marshal it is important to declare the organiser's insolvency. Only then should the Marshal, as a public administration body, initiate the appropriate procedures.

The issue of insolvency of tour operators and entrepreneurs facilitating the purchase of related tourism services has been regulated in chapter 3 of the TERTS. The view that it is not insolvency within the meaning of Article 11 (1) of the BL still seems to be valid ${ }^{27}$. In the light of Article 7 (1) of

25 Form No. 1784 Governmental draft law on tourist events and related tourism services, http://sejm.gov.pl/Sejm8.nsf/druk.xsp?nr=1784 [date of access: 13 October 2019].

26 Form No. 1784 Governmental draft law on tourist events and related tourism services, http://sejm.gov.pl/Sejm8.nsf/druk.xsp?nr=1784.

27 This is also the case in the explanatory memorandum to governmental draft law No. 1784 on tourist events and related tourism services, http://sejm.gov.pl/Sejm8.nsf/ druk.xsp?nr=1784 [date of access: 13 October 2019]. 
the TERTS it should be assumed that insolvency of a tour operator occurs when the tour operator and the entrepreneur facilitating the purchase of related tourism services is not able to provide travellers, in case of its insolvency, with the following:

a) covering the costs of continuation of the package holiday or return to their home country, including in particular transport and accommodation costs, as well as reasonable costs incurred by travellers where the tour operator or entrepreneur facilitating the purchase of related tourism services, despite its obligation, does not ensure such continuation or return,

b) reimbursement of payments made by way of payment for the package holiday or any service paid for by the entrepreneur facilitating the purchase of related tourism services, where, by reasons relating to the tour operator or entrepreneur facilitating the purchase of the related tourism services or persons acting on their behalf, the package holiday or any service paid for by the entrepreneur facilitating the purchase of the related travel services has not or will not be provided,

c) partial reimbursement of the payments made by way of payment for the event corresponding to the part of the package holiday or for any service paid to the entrepreneur facilitating the purchase of related tourism services corresponding to the part of the service which has not been or will not be provided by reasons relating to the tour operator or the entrepreneur facilitating the purchase of the related tourism services, or persons acting on their behalf.

The legislator has provided for rights for travellers regardless of when the tour operator becomes insolvent. These rights arise both if the insolvency occurred at the time of the tourist event, and if the insolvency occurred before or after the event.

The authors will analyse the legal regulations in order to determine what rights the travellers are entitled to in case of the insolvency of the tour operator and to establish the competent authority and the legal nature of these tasks in the context of tasks typical for public administration. Thus, it should be emphasized that the legislator decided that the Marshal of the Voivodship will be the competent authority in a situation of insolvency of the tour operator or entrepreneurs facilitating the purchase 
of related tourism services. In a situation of insolvency, a tour operator or an entrepreneur facilitating the purchase of related tourist services is obliged to submit to the competent Marshal of the Voivodship a statement of relevant content ${ }^{28}$, a list of agreements which have not been or will not be executed, together with information containing the names and contact telephone numbers of the travellers covered by these agreements and contact details of the tour leader or a person representing the tour operator who takes care of the travellers, if such a leader or such a person has been appointed. These documents shall be immediately forwarded by the Marshal to the entity providing financial security. If it is not possible to obtain a statement from the tour operator or the entrepreneur facilitating the purchase of related tourist services, the Marshal shall apply in writing to the entity providing financial security for the payment of funds directly to the travellers without obtaining this statement, provided that the circumstances clearly indicate, that the tour operator or entrepreneur facilitating the purchase of related travel services is not able to honour the contracts concluded with the travellers and to ensure that the costs of continuing the tour or of the return of the travellers to their home country are covered or that travellers are reimbursed for payments or parts of payments made for the tour or related travel services which have not been or will not be provided.

Moreover, the Marshal of the Voivodship or an entity authorised by him or her to issue an advance payment order to cover the costs of continuation of the tourist event or the costs of the return of the travellers to their home country has been authorised to carry out activities related to the organisation of the return of the travellers to their home country if the tour operator or an entrepreneur facilitating the purchase of related tourism

28 According to Article 13 (1), item 1 of the TERTS, the content of the declaration shall include the following information: "I declare that owing to insolvency I am not able to fulfil the contracts referred to in art. 7 (1), item 3 of the Act of 24 November 2017 on tourist events and related tourism services, concluded with travellers from the date of... and ensure coverage of the costs of continuation of the tourist event or the costs of return of travellers to their home country or ensure that travellers are reimbursed for payments or parts there of made as payment for the tourist event or related tourism services, pursuant to the provisions of Article 7 (1), item 1 of the Act of 24 November 2017 on Tourist Events and Related Tourism Services". 
services, despite its obligation, did not ensure this return (Article 14 (1) of the TERTS). To this end, they must be authorised, in the contents of the bank guarantee or insurance guarantee or insurance contract for the benefit of travellers, to issue instructions for the payment of an advance to cover the costs of the continuation of the package or of the return of the travellers.

The entity providing financial security, upon receiving each instruction of the Marshal of the Voivodship or an entity indicated by him or her, shall immediately, but not later than within 3 working days from the date of receiving the instruction, transfer the requested advance to cover the costs of the continuation of the tourist event or the costs of the return of the travellers to their home country (Article 15 (1) of the TERTS). The Marshal shall submit to the entity providing financial security a written settlement of the received advance to cover the costs of continuation of the tourist event or the costs of return of the travellers to their home country, within 60 days from the date of receipt of payment, under pain of the obligation to return this advance.

The question arises as to what if the financial security is not sufficient to cover the continuation of the tourist event or the returnof the travellers to their home country. The legislator has specified that in such situations the entity providing such security is obliged to immediately inform the competent Marshal of the Voivodship and the Insurance Guarantee Fund (Article 20 (1) of the TERTS). The Marshal or an entity indicated by him or her after receiving such information shall apply to the Insurance Guarantee Fund for payment of funds from the Tourist Guarantee Fund. The Insurance Guarantee Fund shall immediately pay the Marshal or an entity indicated by him or her the funds from the Tourist Guarantee Fund to the extent necessary to carry out the task related to the organization of the return of travellers to their home country. The Marshal shall present to the Insurance Guarantee Fund a written settlement of funds from the Tourist Guarantee Fund, within 60 days from the date of receipt of payment, under pain of obligation to return the funds.

According to Article 21 (1) of the TERTS, if the financial security is insufficient to cover the costs and return payments to the travellers, the entity providing such security, immediately after verification of the travellers' requests, shall provide the Insurance Guarantee Fund and the com- 
petent Marshal of the Voivodship with: information on the amounts paid out to those travellers from the financial security, and a calculation of the amounts lacking in order to cover the costs and return payments in relation to each traveller. In addition, the entity providing financial security shall also provide the Insurance Guarantee Fund with requests from travellers who have not received full coverage of costs and reimbursement of payments for the tourist event or that part of the event which has not been or will not be carried out. The Insurance Guarantee Fund shall, immediately upon receipt of the travellers' requests together with information, pay out the amounts due to the travellers, notifying the competent Marshal of the Voivodship and the entity providing financial security of the fact.

\section{LEGAL NATURE OF THE TASKS OF THE MARSHAL IN CASES OF INSOLVENCY OF ENTITIES PROVIDING TOURISM SERVICES}

The analysis of Polish regulations in the scope of tasks and authorities competent in the situation of insolvency of entities providing tourism services leads to the following conclusions. Starting from 1997, the legislator treated tourism services as a licensed activity requiring a licence, a regulated activity requiring a permit or an entry in the relevant register, hence these tasks were entrusted to authorities competent in matters of licences for such activity (President of the Office for Sports and Tourism), or permits (Voivode), or entry in the register of tour operators and entrepreneurs facilitating the purchase of related tourism services (Marshal of the Voivodship) ${ }^{29}$. Starting from 2005, when the Marshal was entrusted with tasks in the event of insolvency of entities providing tourism services, until now it has been assumed that these are tasks in the field of government administration (Article 2 (1) of the TERTS). These tasks in fact boil down to providing financial security in the case of the insolvency of entities providing tourism services and the process of liquidation of the effects

29 Art. 23 of the TERTS. More on the subject of development of the legal nature of the activity of tourist events operators: P. Cybula, O ewolucji warunków świadczenia usług turystycznych z perspektywy interesu konsumenta, iKAR 2(2019): 46-52. 
of insolvency. Both in terms of initiating action before the entity providing financial security and before the Insurance Guarantee Fund.

Moreover, the tasks of the Marshal in a situation of insolvency of entities providing tourism services also include supervisory powers, as the Marshal has been authorised to control compliance with the conditions for carrying out activities specified in the Act, in particular as regards the amount of financial security and payment of contributions to the Tourism Guarantee Fund (Article 30 (1), item 3 of the TERTS). This authority may require the tourist entrepreneur to rectify the deficiencies found as a result of the inspection within a specified period of time (Article 30 (6a) of the TERTS). Moreover, it is also competent to issue a decision on removing the tourist entrepreneur from the register and prohibiting him or her from carrying out the activity included in the register for a period of 3 years - if a tourist entrepreneur is found to be in gross violation of the conditions for carrying out the activity (Article 30 (7), item 1c of the TERTS). The legislator deemed a gross breach of the conditions for carrying out the activity to be: 1) offering or selling tourist events or related tourism services without prior conclusion of a guarantee or agreement, or without conclusion of an agreement and submission of a declaration, 2) evading, despite a call, the obligation to submit a declaration in due time or to pay due contributions to the Tourist Guarantee Fund, 3) evading, despite a call, the obligation to maintain a list of agreements, 4) conclusion by the tourist entrepreneur of subsequent agreements on participation in the tourist event, or facilitating the purchase of related tourist services or accepting payments from travellers for these agreements, despite submitting a declaration of insolvency or in the event that the Marshal of the Voivodship applies for payment of funds from financial security without this declaration, 5) conclusion of agreements for amounts of financial security lower than the minimum amounts of bank or insurance guarantee sums or the minimum guarantee sums of insurance agreements for the benefit of travellers, 6) failure to submit, despite being summoned, a valid document to the Marshal of the Voivodship, 7) performance of activities outside the territorial scope specified in the entry in the register, 8) acceptance of payments from travellers with the omission of a tourist escrow account, despite submitting a declaration. 


\section{SUMMARY}

The Marshal's activities related to the organisation of the return of travellers to their home country are regulated in the provision of Article 14 (1) of the TERTS. In accordance with the above provision, in the event of the insolvency of the tour operator or the entrepreneur facilitating the purchase of related tourist services, the Marshal or an entity authorised by him or her to issue an instruction for the payment of an advance to cover the costs of the continuation of the tourist event or the costs of the return of travellers shall carry out activities related to the organisation of the return of travellers to their home country if the tour operator or the entrepreneur facilitating the purchase of related tourist services, despite its obligation, does not ensure such return.

Two aspects should be noted in this respect. The first one covers issues concerning particular entities and is related to answering the question of who is obliged to perform the tasks imposed by the legislator. The second aspect covers the subject matter issues related to the direct execution of the task. In this respect, one should specify what tasks result from the Act and in what legal form they will be performed.

In this respect, the answer to the questions posed only appears to be simple, as the legislator has imposed this task on the Marshal as a public administration body. There is also no doubt that on the basis of the provision of Art. 2 (1) of the TERTS, this is a governmental administrative task.

A certain problem, however, may be a case in which the Marshal delegates his or her competences to an organisational unit by statutory authority. This raises the question of how wide is the scope of statutory authority delegated by the legislator to the Marshal. It should be noted that the legislator has not limited the possibility of authorisation and uses the broad term of "authorised entity".

In the opinion of the authors, this is not a task to which the provisions of the Code of Administrative Procedure will apply ${ }^{30}$. The above conclusion means that the provision of Article 268a of the CAP together

30 The Act of 14 June 1960, Code of Administrative Procedure, i.e. Journal of Laws 2018, item 2096, as amended, hereinafter referred to as the CAP. 
with the resulting restrictions does not apply within the scope of the authorisation in question. Within the scope of the provision of Article 268a of the CAP, the authorisation applies only to an employee, not to an entity, and as a rule it is connected with the issuance of acts of authority (decisions, provisions) or certificates. This leads to the conclusion that the authorisation contained in Article 14 (1) of the TERTS is an autonomous authorisation and its scope should be interpreted in the context of the tasks provided for in the Act.

The central problem concerning the issued authorisation is to define the scope of the term "entity". It should be stressed that the legislator has not restricted the above scope to organisational units, but has used this concept in the broadest possible sense, i.e. without indicating the characteristics of the entity that can be authorised.

Where a provision does not specify, it must be stated that, if the Marshal has made an authorisation, it is possible to delegate powers to any entity that fulfils the statutory requirements. This means that in the system of Polish law, the entities authorised by the Marshal may be both natural persons and legal persons, as well as organizational units without legal personality.

In this respect, it should be allowed to delegate powers to any entity if the Marshal considers such action to be justified. Obviously, in practice, the criterion to be used by the Marshal making the authorisation should respect the functional elements. The Marshal's task is in fact a public task which he or she is obliged to perform in an effective manner which will ensure the safe return of travellers to their home country.

Certainly, the solution adopted is flexible in nature, as it allows for granting permanent authorisation - for the benefit of a specific organisational unit which has been established, e.g., to achieve such an objective, but also allows for ad hoc authorisation in such a case, depending on the situation.

It should also be noted that the legislator has applied a combined alternative. The task should be performed by the Marshal of the Voivodship "or" a unit authorised by the Marshal, which means that despite granting the authorisation, the Marshal may perform the tasks him- or herself. This may even turn into an obligation to perform a statutory task in a situation where an authorised entity does not perform the entrusted task. It is 
the responsibility of the Marshal acting as a public administration body to perform the task, as well as to take care of its performance.

The performance of the task consists of two parts. The first seems to be the most important from the point of view of the travellers who have not returned to their home country.

From the perspective of the form of activity of an administrative entity performing public administration tasks, these are activities of various natures. First of all, they are material and technical activities consisting in collecting information about travellers, as well as maintaining contact with them. In this respect, the informational activities consisting in providing information about the situation are also important. Further, activities consisting in concluding civil law agreements enabling the actual return of travellers to Poland are not excluded.

The way in which the legislator defines the implementation of the task deserves to be appreciated. In this respect, the act does not determine the way the task is to be performed, but focuses on its purpose, which is to bring travellers back to their home country. Such a solution makes it possible to adjust the form of action in relation to the current need. In this case, there is no statutory "muzzle" that would strictly regulate the form of action performed by the administrative entity. The advantage of the adopted solution is resignation from the traditional ruling forms of administration. In this respect, there is no possibility of shaping the legal relationship by means of an administrative decision.

The second part is financial and accounting activities. In this respect, these tasks are related to the proper flow of funds necessary to cover the task of returning the travelers to their home country. It follows from the statutory regulations that the entity responsible for the implementation of the task is obliged to issue an advance payment to cover the costs of the continuation of the tourist event or the costs of the travellers' return to their home country.

The disposition is addressed to the entity providing financial security, which unconditionally, immediately, but no later than within 3 working days from the date of receipt of the disposition, transfers the requested advance to cover the costs of continuation of the tourist event or the costs of the travellers' return to their home country (Article 15 (1) of the TERTS). 
In the event that the financial security is insufficient to cover the costs of continuation of the tourist event or the costs of the return of the travellers, the Marshal or an entity designated by him or her shall apply to the Insurance Guarantee Fund for payment of funds from the Tourist Guarantee Fund (Article 20(2) of the TERTS).

Within the scope of financial and accounting tasks, the Marshal or the authorized entity are responsible for completing the activities related to the proper flow of financial resources necessary for the proper performance of the task.

The question is whether the new act has introduced effective solutions to protect travellers against the insolvency of a tour operator and the process of liquidation of its effects.

It should be noted that the solution adopted in the Polish system is based on the principle of de-concentration of powers and transferring them as a task outsourced to Voivodship Marshals, who may delegate the tasks to other units. In the opinion of the authors, these are tasks of a strictly public nature, although as a rule they are not carried out by means of authoritative forms of action.

It is difficult to take an unambiguous stance in this respect, establishing whether delegating tasks to a voivodship local government body such as its Marshal is a good solution. In the era of computerisation of administration processes, it would be easy to imagine one central public administration body or a central point (retaining the terminology of the Act), which would be responsible for carrying out activities related to the organisation of travellers' return to their home country. It seems that this would facilitate coordination and uniformity of activities with regard to travellers. In the opinion of the authors, such a solution would be a more effective guarantee of protection for travellers and would comply with Directive 2015/2302. Currently, travellers choose the operator regardless of the place of its seat, and ordering a tourism service is common; it is rather a rule than an exception to the rule.

Unfortunately, checking the existing solutions in practice will always involve the insolvency of the operator, which is in principle a situation that should be avoided. 


\section{COMMENTS DE LEGE FERENDA}

As indicated above, the tasks in the field of protection in the event of insolvency have a public character. They are tasks within the competence of government administration. In order to ensure effective and operational protection of the traveler in the event of insolvency of travel agents, it is necessary that institutional solutions used in the new Act are improved. The authors postulate a change in this respect and propose to entrust these tasks to the government administration bodies, preferably to an existing central public administration body or a new central contact point. These authorities could be responsible for activities related to the organization of travelers' return to the home country and for the efficient coordination of activities bound to it. Some inspiring legal solutions are contained in Art. 18 clause 2 of Directive 2015/2302. In order to fulfil the above obligations, central contact points should be designated by the Member States. According to the Directive, the central contact points shall be responsible for administrative cooperation and the supervision of organizers, operating in different Member States. It seems that the central public administration authority or a specialised central contact point would ensure better legal protection in the event of insolvency of travel agents and would provide a full transposition of the Directive.

\section{REFERENCES}

Cybula, Piotr, 2012, Usługi turystyczne. Komentarz, LEX/el.

Cybula, Piotr, Czubik, Paweł, Pomoc finansowa konsula jako instrument ochrony klienta niewypłacalnego organizatora turystyki, EPS 12 (2014): 20-27.

Cybula Piotr, O ewolucji warunków świadczenia usług turystycznych z perspektywy interesu konsumenta, iKAR 2 (2019): 46-52.

Dolniak, Patrycja, Zakres ochrony finansowych interesów klientów biur podróży na wypadek niewypłacalności przedsiębiorcy w świetle prawa unijnego, Palestra 3 (2018): 12-18.

Dzienis, Paweł, Bezprawność legislacyjna w postaci niewłaściwej implementacji dyrektywy unijnej 90/314/EWG w polskiej judykaturze, EPS 7 (2018): 4-10. Jurkowska-Gomułka, Agata, 2012, Glosa do wyroku TS z dnia 16 lutego 2012 r., C-134/11, LEX/el. 2012. 
Małysa-Ptak, Katarzyna, Zwrot kosztów powrotu do kraju. Glosa do wyroku SN z dnia 15 października 2015 r., II CSK 836/14, PS 7-8 (2016): 171-181.

Marak, Katarzyna, Niewypłacalność organizatora turystyki i przedsiębiorcy ułatwiającego nabywanie powiązanych usług turystycznych - uwagi na tle nowych regulacji prawnych z zakresu turystyki, In: Restrukturyzacja przedsiębiorcy i jego przedsiębiorstwa, M. Kuźnik, A.J. Witosz, ed., Warszawa (2018): Legalis/el.

Nesterowicz, Mirosław, Dyrektywa Unii Europejskiej o imprezach turystycznych i powiązanych usługach turystycznych, jej implementacja do prawa polskiego i odpowiedzialność biur podróży, Przegląd Sądowy 9 (2018): 44-57.

Sekuła-Leleno, Małgorzata, Legitymacja procesowa czynna klientów niewypłacalnych biur podróży do samodzielnego dochodzenia roszczeń przed sądem. Glosa do uchwały SN z dnia 19 maja 2016 r., III CZP 18/16, Glosa 1 (2017): 123-132.

Sondej, Marek, Klient niewypłacalnego biura podróży może samodzielnie dochodzić zwrotu dokonanych wpłat, LEX/el. 2017.

Szafran, Dominika, Ochrona konsumenta w razie niewypłacalności biura podróży, Acta Erasmiana XIII (2016), M. Sadowski, ed.: 100-109.

Wanat-Połeć, Elżbieta Jadwiga, Sordyl, Grażyna Anna, Wzmocnienie ochrony konsumentów niewypłacalnych touroperatorów w Polsce a koncepcja utworzenia Turystycznego Funduszu Gwarancyjnego, Annales Universitatis Maria Curie-Skłodowska, Lublin, Vol. XLIX, 4 (2015): DOI: 10.17951/h.2015.49.4.633, http://oeconomia.annales.umcs.pl.

Zawistowska, Hanna, Systemy zabezpieczenia finansowego interesów nabywców imprez turystycznych na wypadek niewypłacalności ich organizatorów w państwach członkowskich UE, In: P. Cybula, J. Raciborski, ed., Turystyka a prawo. Aktualne problemy legislacyjne i konstrukcyjne, (2008) Wyższa Szkoła Turystyki i Ekologii w Suchej Beskidzkiej, Sucha Beskidzka-Kraków, http://wtir.awf.krakow.pl/pdf/rozne/zaklad_prawa/turystyka_a_prawo/21-hanna_zawistowska.pdf. 